\title{
Phaleria macrocarpa (Boerl.) Scheff Fruit: A Potential Source of Natural Antioxidant
}

\author{
Rudi Hendra, Yuli Haryani \\ Department of Chemistry, Faculty of Mathematics and Natural Sciences, University of Riau, \\ Pekanbaru, Riau, Indonesia \\ Scientific Consortium of Drug Discovery and Development, University of Riau, \\ Pekanbaru, Riau, Indonesia
}

\begin{abstract}
Phaleria macrocarpa (Scheff.) Boerl is originated from Papua Island, Indonesia. There have been only limited attempts to explore the biological properties of this plant in relation to their medicinal use. This study aimed to examine antioxidant activity of P. macrocarpa fruit. Extraction of pericarp and mesocarp of P. macrocarpa were performed using soxhlet method with ethyl acetate as the solvent. Antioxidant activity was characterized in various in vitro model systems, including DPPH and ferric reducing antioxidant assay. We found that the highest amount of phenolic compounds and flavonoids were found in the pericarp $(58.3 \pm 0.07$ $\mathrm{mg} / \mathrm{g}$ DW and $127.8 \pm 1.08 \mathrm{mg} / \mathrm{g}$ DW, respectively). The results showed that pericarp had higher antioxidant activity $\left(\mathrm{IC}_{50}=122.4 \pm 1.14 \mu \mathrm{g} / \mathrm{ml}\right)$ compared to mesocarp $\left(\mathrm{IC}_{50}=175.48 \pm 1.75 \mu \mathrm{g} /\right.$ $\mathrm{ml}$ ). In conclusion, the result of this study indicated the possible application of $P$. macrocarpa as a source of natural antioxidant compound.
\end{abstract}

Keywords: antioxidant, Phaleria macrocarpa, phenolic compounds, flavonoids

\section{Introduction}

Phaleria macrocarpa (Scheff.) Boerl is commonly known as crown of god or mahkota dewa. It is originated from Papua Island, Indonesia. This plant is popular in Indonesia. P. macrocarpa grows throughout the year in tropical area. Its fruit has eclipse shape with $\varnothing \pm 3 \mathrm{~cm}$. The colour of the fruit is green before ripening and red when fully ripe. ${ }^{1}$ Traditionally, $P$. macrocarpa has been used to help reducing symptoms of cancer, impotency, hemorrhoids, diabetes mellitus, allergies, liver diseases, heart diseases, kidney diseases, acne, stroke, migraine, and various skin diseases. ${ }^{2}$ Its fruit is usually consumed in the form of boiled water extract.

Despite the extensive use by Indonesian people, there have been only limited attempts to explore the biological properties of this plant in relation to their medicinal uses. This study aimed to examine antioxidant activity

Corresponding author: Rudi Hendra. Department of Chemisty, Faculty of Mathematics and Natural Sciences, University of Riau, Pekanbaru, Riau, Indonesia. Email: rudi.hendra@lecturer.unri.ac.id Received: 2 February 2018. Revised: 22 March 2018. Published: 23 April 2018. 
of the extract of pericarp and mesocarp from P. macrocarpa fruit.

\section{Methods}

Extraction

The fruits of $P$. macrocarpa were obtained from Faculty of Mathematics and Natural Sciences, University of Riau, Pekanbaru, Riau, Indonesia. The mesocarp and pericarp were air-dried for 7 days. The extractions were performed using soxhlet. Briefly, airdried powders of each part of $P$. macrocarpa fruit $(0.5 \mathrm{~g})$ were weighed and placed into a $100 \mathrm{ml}$ conical flask. About $40 \mathrm{ml}$ of ethyl acetate was added, followed by $10 \mathrm{ml}$ and 6 $\mathrm{M} \mathrm{HCl}$ solution. The mixture was magnetic stirred, placed in a sample flask $(250 \mathrm{ml})$, and refluxed for 2 hours at $90^{\circ} \mathrm{C}$. The mixture was filtered using Whatman No.1 and dried using vacuumed rotary evaporator at $40{ }^{\circ} \mathrm{C} .{ }^{3}$

\section{Total phenolics assay}

Total phenolic compounds were determined according to Ismail et al. ${ }^{4}$ About $0.5 \mathrm{ml}$ of each extract, $2.5 \mathrm{ml}$ Folin-Ciocalteu reagent, $2 \mathrm{ml}$ of $7.5 \%$ (w/v) $\mathrm{Na}_{2} \mathrm{CO}_{3}$ were vortexmixed and incubated at room temperature for 90 minutes. The absorbances were measured using visible spectrophotometer (Novaspec II Visiblespectro) at $765 \mathrm{~nm}$. The results were expressed as mg/g dry weight (DW).

\section{Total flavonoid assay}

The total flavonoid compounds in each extract was determined according to Ismail et $a l .{ }^{4}$ An aliquot $(0.1 \mathrm{ml})$ of extract was added to $0.3 \mathrm{ml} 5 \%(\mathrm{w} / \mathrm{v}) \mathrm{NaNO}_{2}$ and incubated for 5 minutes. About $0.3 \mathrm{ml} \mathrm{10 \% (w/v)} \mathrm{AlCl}_{3}$ and $2 \mathrm{ml} 1 \mathrm{~N} \mathrm{NaOH}$ was added and the total volume was added up to $5 \mathrm{ml}$ with distilled water. The absorbance was measured using visible spectrophotometer (Novaspec II Visiblespectro) at $510 \mathrm{~nm}$. The results were expressed as mg/g DW.
Antioxidant activity

DPPH assay

The free radical scavenging activity of the extract was determined using the DPPH assay. Briefly, $1 \mathrm{ml}$ extract was mixed with $3 \mathrm{ml} 0.1 \mathrm{mM}$ solution of 1,1-diphenyl-2picryl-hydrazil (DPPH) in methanol. After incubation at room temperature for 30 minutes in dark condition, the absorbance of the mixture was mesured using a visible spectrophotometer (Novaspec II Visblespectro) at $517 \mathrm{~nm}$. Ascorbic acid and $\alpha$-tocopherol were used as positive controls. Free radical scavenging activity from the sample was calculated according to the following formula: $\left[\left(\mathrm{A}_{0}-\mathrm{A}_{1}\right) / \mathrm{A}_{0}\right] \times 100 \%$; where $A_{0}$ was the absorbance of the control and $A_{1}$ was the absorbance of the sample.

\section{Ferric-reducing antioxidant power (FRAP) assay}

About $1 \mathrm{ml}$ (concentration of 100, 150, 200, 250 , and $300 \mu \mathrm{g} / \mathrm{ml}$ ) of extracts were mixed with $2.5 \mathrm{ml}$ of potassium phosphate buffer (0.2 M, pH 6.6) and $2.5 \mathrm{ml}$ of potassium ferricyanide $(1 \mathrm{~g} / 100 \mathrm{ml})$. The mixture was incubated at $50{ }^{\circ} \mathrm{C}$ for 20 minutes. Trichloroacetic acid (10\%) was added to the mixture to stop the reaction. Equal volume of distilled water was added followed by 0.5 $\mathrm{ml}$ ferric chloride $(0.1 \mathrm{~g} / 100 \mathrm{ml})\left(\mathrm{FeCl}_{3}\right)$. The analysis was conducted triplicate. The above procedures were repeated with BHT, ascorbic acid and $\alpha$-tocopherol as positive controls. The percentage of antioxidant activity in FRAP assay of the samples was calculated according to the following formula: $\left(\mathrm{A}_{1}\right.$ $\left.A_{0}\right) / A_{1} \times 100 \%$, where $A_{0}=$ absorbance of the control (potassium phosphate buffer + FRAP reagent) and $\mathrm{A}_{1}=$ absorbance of the extract.

\section{Results and Discussion}

Phenolic and flavonoid contents

Phenolic is a class of secondary metabolites synthesized by plant which are utilized 
Table 1. Total phenolic and flavonoid contents

\begin{tabular}{ccc}
\hline Extract & Total phenolic $(\mathbf{m g} / \mathbf{g}$ DW) & Total flavonoidb(mg/g DW) \\
\hline Pericarp & $58.3 \pm 0.07$ & $127.8 \pm 1.08$ \\
Mesocarp & $55.49 \pm 0.17$ & $80.9 \pm 1.01$ \\
\hline
\end{tabular}

primarily for protection against stress. Several biological activities are associated with this compound, such as antioxidant, antimutagenic, anticarcinogenic, antiinflammatory and antimicrobial activities. ${ }^{5-8}$

As presented in Table 1, we found that the highest amount of phenolic compounds and flavonoids were found in pericarp $(58.3 \pm 0.07$ $\mathrm{mg} / \mathrm{g}$ DW) and $127.8 \pm 1.08 \mathrm{mg} / \mathrm{g}$ DW, respectively). In this study, the total flavonoid content was higher compared to the previous study which extracted $P$. macrocarpa dry fruit (without seed) using soxhlet with methanol as the solvent.

\section{Antioxidant activity}

Antioxidant is defined as a substance which significantly delays or inhibits oxidation process. Antioxidant activity is measured indirectly by determining the inhibition rate of oxidation process at the presence of antioxidant. ${ }^{9}$ DPPH is widely used to determine the antioxidant activity of the plant extract. ${ }^{10,11}$ The results showed that pericarp had higher antioxidant activity $\left(\mathrm{IC}_{50}=122.4 \pm 1.14 \mu \mathrm{g} / \mathrm{ml}\right)$ compared to mesocarp $\left(\mathrm{IC}_{50}=175.48 \pm 1.75 \mu \mathrm{g} /\right.$ $\mathrm{ml})$.

The ability of extracts to reduce iron (III) to iron (II) was determined and compared to butylated hydrotoluene (BHT) which are known to be strong reducing agents. We found that the ability to reduce iron in the dose dependent manner in pericap and mesocarp were $91.66 \%$ and $53.28 \%$, respectively. This finding was slightly lower compared with previous study which used methanol as the solvent. $^{7}$

The antioxidant activity of $P$. macrocarpa fruit might be due to the presence of phenolic and flavonoid compounds. Karimi et al, ${ }^{12}$ reported the presence of kaempferol, myricetin, naringin, quercetin, and rutin as the major flavonoids present in P. macrocarpa fruit. The correlation between flavonoids and their antioxidant activity might be due to the presence of a 3-hydroxyl group in the heterocyclic ring while additional hydroxyl or methoxyl groups at positions 3,5 and 7 of rings $\mathrm{A}$ and $\mathrm{C}$ seem to be less important. ${ }^{13-14}$ This finding was in accordance with previous study which investigated antioxidant activity of flavonoids. ${ }^{15}$ Highly active flavonoids possess a 3'4'-dihydroxy occupied B ring and/or 3-OH group.

\section{Conclusion}

In conclusion, the result of this study indicated the possible application of $P$. macrocarpa as a source of natural antioxidant compound.

Table 2 . The $\mathrm{IC}_{50}$ values of the extracts

\begin{tabular}{lcc}
\hline Extract & DPPH $(\boldsymbol{\mu g} / \mathbf{m l})$ & FRAP $(\boldsymbol{\mu g} / \mathbf{m l})$ \\
\hline Pericarp & $122.4 \pm 1.14$ & $47.8 \pm 1.34$ \\
Mesocarp & $175.48 \pm 1.75$ & $71.2 \pm 1.24$ \\
BHT & $78.7 \pm 1.01$ & $24.8 \pm 1.32$ \\
\hline
\end{tabular}




\section{Acknowledgements}

The author would like to thank the Faculty of Biotechnology and Biomolecular Sciences, Universiti Putra Malaysia for the laboratory facilities and Faculty of Mathematics and Natural Sciences, University of Riau for providing the samples.

\section{Funding}

None.

\section{Conflict of Interest}

None declared.

\section{References}

1. Altaf R, Asmawi MZB, Dewa A, et al. Phytochemistry and medicinal properties of Phaleria macrocarpa (Scheff.) Boerl. extracts. Pharmacognosy Reviews. 2013;7(13):73-80.

2. Parhizkar S, Zulkifli SB, Dollah MA. Testicular morphology of male rats exposed to Phaleria macrocarpa (mahkota dewa) aqueous extract. Iranian Journal of Basic Medical Sciences. 2014;17(5):384-390.

3. Vukics $\mathrm{V}$, Toth $\mathrm{BH}$, Ringer $\mathrm{T}$, et al. Quantitative and qualitative investigation of the main flavonoids in heartsease (Viola tricolor L.) Journal of Chromatography Sciences. 2008;46:97-101.

4. Ismail HI, Chan KW, Mariod AA, et al. Phenolic content and antioxidant activity of cantaloupe (Cucumis melo) methanolic extracts. Food Chemistry. 2010;119(2): 643-647.

5. Inglett GE, Chen D. Contents of phenolics and flavonoids and antioxidant activities in skin, pulp, and seeds of miracle fruit. Journal of Food Science. 2011;76(3):C479-C482.

6. Falleh H, Ksouri R, Chaieb $\mathrm{K}$, et al. Phenolic composition of Cynara cardunculus L. organs, and their biological activities. Comptes Rendus
Biologies. 2008;331(5):372-379.

7. Hendra R, Ahmad S, Oskoueian E, et al. Antioxidant, antiinflammatory and cytotoxicity of Phaleria macrocarpa (Boerl.) Scheff Fruit. BMC Complementary and Alternative Medicine. 2011;11(1):110-115.

8. Rohyami Y. Assessment of flavonoid compunds on Phaleria macrocapa methanol extract. Logic Journal. 2008;5:1-16.

9. Lobo V, Patil A, Phatak A, et al. Free radicals, antioxidants and functional foods: Impact on human health. Pharmacognosy Reviews. 2010;4(8):118126.

10. Kedare SB, Singh RP. Genesis and development of DPPH method of antioxidant assay. Journal of Food Science and Technology. 2011;48(4):412422.

11. Karimi E, Oskoueian E, Hendra R, et al. Evaluation of Crocus sativus L. stigma phenolic and flavonoid compounds and its antioxidant activity. Molecules. 2010;15(9):6244-6256.

12. Hendra R, Ahmad S, Sukari A. Flavonoid analyses and antimicrobial activity of various parts of Phaleria macrocarpa (Scheff.) Boerl fruit. International Journal of Molecular Sciences. 2011;12 (6):3422-3431

13. Kefayati Z, Motamed SM, Shojaii A, et al. Antioxidant activity and phenolic and flavonoid contents of the extract and subfractions of Euphorbia splendida Mobayen. Pharmacognosy Research. 2017;9(4):362-365.

14. Hendra R, Keller PA. Flowers in Australia: phytochemical studies on the Illawarra flame tree and alstonville. Australian Journal of Chemistry. 2016;69:925-927.

15. Grassi D, Desideri G, Ferri C. Flavonoids: antioxidants against atherosclerosis. Nutrients. 2010;2(8):889-902. 